\section{Una nuova classe di composti ad azione anti- ulcera: gli esteri farnesilacetici}

Il primo accenno ad un fattore alimentare necessario per il mantenimento dell'integrità anatomica della mucosa gastrica risale al $1929 \mathrm{ed}$ è dovuto a 1 1) ${ }^{1,2}$ che postulo l'esistenza di un fattore antiulcera nel corso delle ricerche che dovevano portarlo alla scoperta della vitamina $K$.

I tentativi di isolare questa cosiddetta Vitamina IT (U-factor, Antiulcusfaktor) dal cavolo cappuccio e da altri vegetali non hanno finora avuto, per quanto mi consta, alcun successo.

L'attribuzione di attività antiulcera al metionin-metilsolfonio presente nel cavolo cappuccio ${ }^{3}$ si è dimostrata infondata ${ }^{4}$;o stesso può dirsi per la $L(+)$-glutammina ${ }^{5}$.

Anche nel nostro laboratorio i tentativi di isolamento della vitamina $U$ sono stati infruttuosi tanto da indurmi a battere un'altra strada, che pur deviando dal campo delle sostanze naturali ha consentito di riconoscere l'esistenza di una nuova classe di composti sintetici dotati di elevata attività antiulcera.

Dalla letteratura sembra risultare che il fattore $U$ è liposolubile ${ }^{\mathfrak{b}}$; d'altro lato era stato messo in evidenza che nei polli, in seguito a diete carenzate, si formano erosioni nel ventriglio: il fattore la di cui carenza è responsabile di questa forma morbosa ("antigizzard-erosion factor") è liposolubile, è in rapporto con la vitamina $K$ ed è presente, tra l'altro, nel cavolo?,8. Nel cavolo è anche presente la vitamina $K_{\mathbf{x}}$.

Mi sono perciò chiesto se l'attività antiulcera potesse dipendere da composti del tipo di quelli delle catene laterali terpeniche delle vitamine $K$ naturali, ed ho sperimentato il farnesolo e il fitolo, usando come test l'ulcera da istamina nella cavia protetta con tripelennamina, test molto sensibile e da noi largamente studiato ed usato per l'accertamento dell'attività U degli estratti di cavolo ${ }^{9,10}$.

La scelta del farnesolo come punto di partenza di queste ricerche è stata particolarmente fortunata, perchè a differenza del fitolo, che è risultato inattivo, questo alcool terpenico ha dimostrato una buona attività antiulcera, non solo per via orale, ma anche parenterale, a dosi relativamente basse $(10 \mathrm{mg} / \mathrm{kg})$.

Proseguendo le ricerche su terpeni naturali analoghi, si mise in evidenza l'importanza della struttura isoprenica per l'azione antiulcera. Vennero allora preparati diversi composti sintetici a partire dal farnesolo, tra cui l'acido farnesilacetico, che si dimostrò pure attivo. La massima attività fu però riscontrata negli esteri di questo acido, e in particolare nei farnesilacetati di etile, butile, laurile, allile, propargile, cicloesile, fitile, geranile, tetraidrogeranile e farnesile, che si dimostrarono attivi a dosi inferiori a $5 \mathrm{mg} / \mathrm{kg}$.

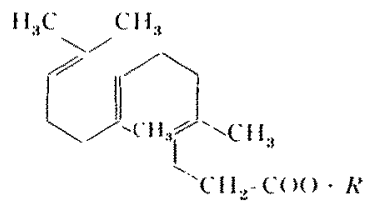

Questi nuovi composti" sono particolarmente interessanti per la tossicità praticamente trascurabile unita ad un'elevata attività antiulcera, che non c̀ in rapporto con veruna azione neurovegetativa; non sono inlatti anticolinergici, nè ganglioplegici, nè antistaminici, nè spasmolitici, e neppure modificano la secrezione gastrica. II loro meccanismo di azione, peraltro non chiarito, sembra consistere in un effetto protettivo e rigenerativo di cleterminate mucose. Estese ricerche farmacologiche sui termini più interessanti dellat serie hanno messo in evidenza che l'azione antiulceral $d$, se non l'unical, certamente di gran lunga la più importante tra le poche osservate, sì cla far pensare ald una vera e propria specificità in questo campo.

Preliminari esperienze cliniche nell'ulcera gastrica e nell'ulcera duodenale confermano i risultati della sperimentazione sull'animale.

Summary. In a new series of synthetic compounds, the farnesyl acetic esters, some specifically effective elrugs for the treatment of experimental gastric ulcer have been singled out. They have shown to be completely lacking of neurovegetative actions.

E. AnAMI

Istituto De Angeli, Milamo (Italy), July $11,1962$.

$1 \mathrm{H}$, Dan, Biorhem. Z, $24 \pi, 175,(19,2)\}$

g H. 1) AM, Biochen. $Z$ 2.20, 15K (1930)

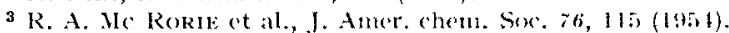

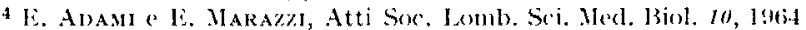
(1955).

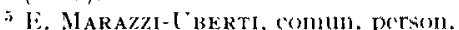

${ }^{6}$ (i. Cuener, Stanford Med. Bull. $s, 111$ (ISivi).

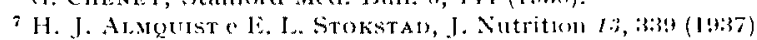

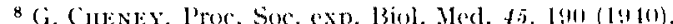

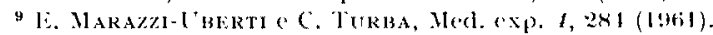

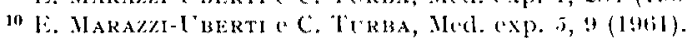

11 Brit. lat. Appl. $\mid \times \times 12 / 4 i 1$.

\section{Absence of Phosphogluconate Pathway Activity in Normal and in Ethanol-Intoxicated Slices from Rat Brain}

The question of whether the brain possesses a functional phosphogluconate or 'direct oxidative' pathway has not been resolved. Although the glucose-6-phosphate and 6-phosphogluconate dehydrogenases can be demonstrated in brain ${ }^{1}$, the role of this pathway has been considered negligible ${ }^{2}$. Ethanol has been shown to influence the $\gamma$ aminobutyric acid content of rat brain ${ }^{3}$ and since the metabolism of the latter compound serves as a by-pass of the $\alpha$-ketoglutarate-succinate transformation in the citric acid cycle, it was decided to investigate the influence of ethanol on the pathway of glucose oxidation in this tissue.
Slices of cerebral cortex $(350 \mathrm{mg})$ from $200-250 \mathrm{~g}$ Sprague-l awley albino rats were incubated in special flasks ${ }^{4}$ with $20 \mathrm{mg}$ glucose containing $0.2 \mu \mathrm{C}$ of either glucose-1- $\mathrm{C}^{14}$ or glucose-6- $\mathrm{C}^{14}$ in $5 \mathrm{ml}$ of Krebs-Ringer bicarbonate solution in which the $\mathrm{KCl}$ concentration was increased to 0.1 molar. This approximates the $\mathrm{K}^{+} \mathrm{con}$ -

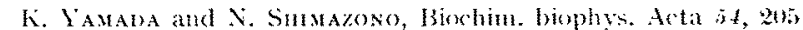

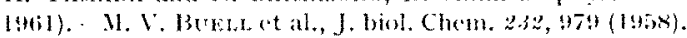

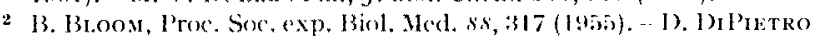

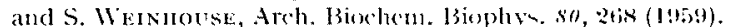

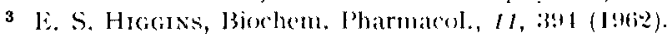

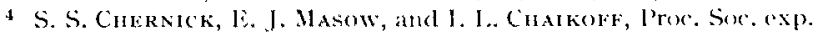
biol. Med. $73,318(1450)$.

5. J)ickens and (X. 1). (inesurete, Biochent. J. 29, 1dtis (1935). 